\title{
PENGELOLAAN LINGKUNGAN BERBASIS KEMITRAAN MASYARAKAT DI PESANTREN ILMU GIRI, KABUPATEN BANTUL
} PESANTREN DAN

\author{
Wijaya $^{1}$, Baiquni' ${ }^{2}$, dan Bakti Setiawan ${ }^{3}$
}

Fakultas Geografi ${ }^{1}, 2$, Fakultas Teknik Universitas Gadjah, Mada, Yogyakarta, Indonesia ${ }^{3}$ wijayageo@gmail.com

Diterima :juni 2013 ; Direvisi :September 2014.; Dipubikasikan: 31 Maret 2015

ABSTRAK Tujuan penelitian ini adalah untuk : (1) mengetahui bentuk-bentuk kegiatan pengelolaan lingkungan hasil kemitraan Pesantren Ilmu Giri dengan masyarakat, (2) mengetahui kurikulum, materi dan metode pembelajaran berbasis lingkungan yang diterapkan Pesantren Ilmu Giri kepada jamaah dan santri, dan (3) mengetahui faktor-faktor yang mempengaruhi keberhasilan Pesantren Ilmu Giri dalam menumbuhkan kesadaran lingkungan di masyarakat dusun Nogosari. Wawancara mendalam, observasi partisapatif, focus group discussion (FGD), dan dilengkapi kajian pustaka serta dokumentasi merupakan teknik utama dalam penggalian data. Data yang terkumpul lalu dianalisis secara deskriptif kualitatif. Tesis ini menemukan bahwa : (1) Pesantren Ilmu berhasil dalam pengelolaan lingkungan alam, sosial dan budaya dalam bentuk-bentuk kegiatan seperti : (a) penghijauan melalui hutan santri dengan konsep eco-religi; (b) Pesantren Ilmu Giri menggali, mengangkat dan melestarikan budaya tradisi lokal; (c) Pesantren Ilmu Giri mengangkat ekonomi masyarakat melalui lahirnya Lembaga Keuangan Mikro (LKM); (d) Pesantren Ilmu Giri mengkampayekan makanan ekologis dan menolak penggunaan pupuk kimia dan pestisida. (2) Pesantren Ilmu Giri tidak memiliki kurikulum sebagaimana lazimnya pada pesantren-pesantren modern yang memiliki santri dan pondok. Ilmu Giri hanya memiliki jamaah mujahadah dan santri Taman Pendidikan Al-Qur'an (TPA). Jamaah mujahadah dan santri TPA inilah yang menjadi sasaran dakwah pesantren. Materi dan metode pembelajaran di pesantren diarahkan pada etika lingkungan dan pemberdayaan masyarakat dalam rangka mencapai visi pesantren, yaitu memecahkan masalah sosial keterbelakangan, kebodohan, kemiskinan dan kerusakan lingkungan hidup. Inti pengajaran bagi jamaah dan santri adalah menanamkan pengetahuan dan kearifan dalam hidup mereka, selain mempelajari al-Quran. Materi pengajaran berbasis alam sekitar pesantren, khususnya alam hutan dan budaya tradisi. (3) Ada 4 hal yang melatarbelakangi Pesantren Ilmu Giri berhasil dalam kegiatan menumbuhkan kesadaran lingkungan, yaitu : pertama modal sosial dan modal spiritual pengasuh pesantren; kedua ketokohan dan strategi kepemimpinan pengasuh pesantren; ketiga dukungan warga lokal pesantren; dan keempat dukungan pemberitaan media massa (pers) terkait dengan kegiatan pesantren. Selain keberhasilan, juga ditemukan beberapa kendala / kelemahan dalam pengelolaan lingkungan berbasis kemitraan pesantren dan masyarakat, yaitu (a) dakwah dan ceramah-ceramah lingkungan sulit diterima jamaah karena keterbatasan pendidikan; (b) merubah pola pikir (mind set) masyarakat terhadap kelestarian lingkungan; (c) tingkat ekonomi masyarakat yang rendah; (d) akses, moda transportasi serta ketersedian air bersih yang terbatas; (e) domisili pengasuh jauh dari pesantren; (f) konflik dan gesekan pengasuh pesantren dan masyarakat lokal.

Kata kunci: kemitraan dan pesantren; pengelolaan lingkungan

ABSTRACT The purpose of this study was to: (1) determine the forms of environmental management activities result of the partnership Pesantren Science Giri with the public, (2) determine the curriculum, materials and methods based learning environment that is applied Pesantren Science Giri told pilgrims and students, and (3) determine the factors that influence the success of Science Giri Pesantren in growing environmental awareness in society Nogosari hamlet. In-depth interviews, observation partisapatif, focus group discussion (FGD), and include a literature review and documentation is a major technique in data mining. The data collected is then analyzed descriptively qualitative. This thesis found that: (1) Boarding School of Science succeeded in the management of the natural environment, social and cultural forms of activities such as: (a) afforestation through forest students to the concept of eco-religion; (b) Science Giri Pesantren digging, lifting and preserving local cultural traditions; (c) Science Giri Pesantren lift the local economy through the birth of Microfinance Institutions (MFIs); (d) Science Giri Pesantren mengkampayekan ecological food and refuse the use of chemical fertilizers and pesticides. (2) Science Giri Pesantren not have a curriculum as usual in modern boarding schools that have students and cottage. Science has only Giri mujahadah pilgrims and students Taman Pendidikan AlQur'an (TPA). Mujahadah worshipers and students landfill that is the target of propaganda boarding. Materials and methods of teaching in schools directed at environmental ethics and community empowerment in order to achieve the 
vision of schools, ie solving social problems of backwardness, ignorance, poverty and environmental damage. Core instruction for pilgrims and students are imparting knowledge and wisdom in their lives, in addition to studying the Koran. Nature-based teaching materials about schools, especially natural forests and cultural tradition. (3) There are four things behind Giri Pesantren Science succeeded in growing environmental awareness activities, namely: first spiritual and social capital pesantren; The second persona and leadership strategies pesantren; The third support local residents boarding; and fourth support of the mass media (press) related to boarding activities. In addition to success, also found several obstacles / weaknesses in the environmental management of schools and community-based partnerships, namely (a) propaganda and speeches tough environment because of the limitations of the education received by the congregation; (b) change the mindset (mind set) community towards environmental sustainability; (c) the low level of the public economy; $(d)$ access, modes of transport and the limited availability of fresh water; (e) domicile caregivers away from school; (f) the conflict and friction pesantren and local communities.

Key words: partnership and boarding; enviromental management

\section{PENDAHULUAN}

Kerusakan lingkungan dan bencana alam akhirakhir ini sering terjadi terkait dengan ulah manusia yang tidak bisa dilepaskan dari gaya hidup yang konsumerisme dan eksploitasi berlebihan. Kebutuhan manusia dari waktu ke waktu selalu mengalami peningkatan, sementara sumber daya alam mempunyai keterbatasan menurut ruang dan waktu, sehingga memicu terjadinya eksploitasi tanpa memperhatikan kemampuan alam, dan pada akhirnya menganggu keseimbangan alam dan memicu terjadinya bencana ekologi dan konflik lingkungan. Menurut Baiquni dan Susilawardani (2002), konflik lingkungan yang ditimbulkan dari penguasaan sumber daya alam akan berakibat pada marjinalisasi kepentingan masyarakat.

Kerusakan dan pencemaran lingkungan itu disebabkan pola pembangunan yang dilakukan mengabaikan prinsip-prinsip dasar lingkungan yang tidak lagi memperhatikan keberlanjutan pembangunan. Terjadinya berbagai bencana di Indonesia dalam beberapa tahun terakhir merupakan indikasi nyata bahwa krisis lingkungan sudah menjadi ancaman serius bagi bangsa ini. Salim (2006), menyatakan bahwa pola pembangunan kita selama ini telah melewati ambang batas daya dukung lingkungan. Akibatnya, kita pun menuai bencana ekologis di mana-mana.

Dalam konteks Indonesia, menurut Hermawan (2007) selama lebih dari tiga dasawarsa di penghujung Abad 20, kita telah menyaksikan pembangunan berwatak teknokratis selama ini, eksploitasi alam dimaksimalkan untuk memenuhi kebutuhan konsumsi nasional dan pertumbuhan ekonomi, sementara upayau'paya pemeliharaan dan konservasi diabaikan. Pendapat senada juga dikemukan oleh Setiawan (2007), bahwa telah terjadi proses komersialisasi, kapitalisasi, privatisasi lingkungan dan sumber daya alam yang meningkat sesuatu yang sangat mengkhawatirkan dalam situasi jumlah penduduk dan kemiskinan yang tinggi di Indonesia.
Kerusakan lingkungan pada tataran perspektif dan implementasi kebijakan sulit untuk dipulihkan karena menyangkut manusia dan aktivitasnya. Meningkatnya aktivitas manusia dalam memanfaatkan sumberdaya alam didorong oleh meningkatkatnya kebutuhan untuk pangan, sandang dan papan serta pemenuhan kebutuhan lainnya. Fenomena kontradiktif terjadi, disatu sisi kebutuhan dan pemanfaatan sumber daya alam selalu meningkat seiring dengan peningkatan jumlah penduduk dan dorongan mencapai kemajuan, disisi lain terjadi kemerosotan sumber daya dan lingkungan sebagai akibat penggunaan sumber daya alam secara berlebihan dan kegagalan pengelolaan (Sutikno, 1983 dalam Baiquni, 2002).

Berangkat dari berbagai kasus kerusakan lingkungan seperti telah disinggung diatas jika ditarik benang merah, akar persoalannya karena kita melupakan atau meninggalkan peran salah satu lembaga pendidikan tradisional, yaitu pesantren yang ternyata telah lama menjalankan peran sosial. Peran sosial yang dimainkan pesantren merupakan penjabaran nilai-nilai hidup keagamaan bagi kemaslahatan masyarakat luas sekaligus sebagai bukti bahwa pesantren berhasil merespon persoalanpersoalan kemasyarakatan.

Tujuan penelitian ini adalah sebagai berikut: (a) mengetahui bentuk-bentuk kegiatan pengelolaan lingkungan yang telah dilakukan oleh kemitraan Pesantren Ilmu Giri dan masyarakat; (b) mengetahui kurikulum, materi dan metode pembelajaran berbasis lingkungan yang diterapkan Pesantren Ilmu Giri kepada santri; (c) engetahui faktor-faktor yang mempengaruhi keberhasilan Pesantren Ilmu Giri dalam pengelolaan lingkungan di Desa Selopamioro.

Manusia dalam memenuhi kebutuhan hidupnya memerlukan sumber daya alam, berupa tanah, air dan udara serta sumberdaya alam yang lain. Namun demikian, harus disadari bahwa sumber daya alam yang kita perlukan mempunyai keterbatasan di dalam 
banyak hal, yaitu keterbatasan tentang ketersediaan menurut kuantitas dan kualitasnya. Sumber daya alam tertentu juga mempunyai keterbatasan ruang dan waktu (Sudarmadji, 2008).

Menurut Bintarto (1992), lingkungan hidup manusia terdiri atas lingkungan fisik (sungai, udara, air, rumah dan sebagainya), lingkungan biologis (organisme hidup, antara lain hewan, tumbuhtumbuhan, dan manusia, dan lingkungan sosial (sosial kemasyarakatan, sikap kerohanian, dan sebagainya). Dengan kata lain, manusia adalah bagian dari lingkungannya sendiri, baik lingkungan alam maupun lingkungan sosial. Bahkan antar manusia dengan lingkungannya terjalin hubungan timbal balik dan saling mempengaruhi. Dalam interaksi yang terjadi secara terus menerus tersebut manusia mendapatkan pengalaman tentang lingkungannya.

Perlindungan dan pengelolaan lingkungan hidup adalah upaya sistematis dan terpadu yang dilakukan untuk melestarikan fungsi lingkungan hidup dan mencegah terjadinya pencemaran dan/atau kerusakan lingkungan hidup yang meliputi perencanaan, pemanfaatan, pengendalian, pemeliharaan, pengawasan, dan penegakan hukum (UU Nomor 32 Tahun 2009 tentang PPLH).

Perlindungan dan pengelolaan lingkungan hidup adalah upaya sistematis dan terpadu yang dilakukan untuk melestarikan fungsi lingkungan hidup dan mencegah terjadinya pencemaran dan/atau kerusakan lingkungan hidup yang meliputi perencanaan, pemanfaatan, pengendalian, pemeliharaan, pengawasan, dan penegakan hukum . Pendapat lain dikemukakan oleh Setiawan (2000) bahwa pengelolaan lingkungan adalah suatu proses intervensi publik yang sistematis dan menerus dalam pengalokasian dan pemanfaatan lingkungan dan sumber daya alam untuk memecahkan persoalan-persoalan lingkungan saat ini dan untuk menuju pembangunan yang berkelanjutan.

Terpeliharanya keberlanjutan fungsi lingkungan hidup merupakan kepentingan manusia sehingga menuntut tanggung jawab, keterbukaan, dan peran masyarakat yang dapat disalurkan melalui orang perseorangan, organisasi lingkungan hidup, seperti lembaga swadaya masyarakat, lembaga pendidikan pesantren, kelompok masyarakat adat, dan lain-lain untuk memelihara dan meningkatkan daya dukung dan daya tampung lingkungan hidup yang menjadi tumpuan keberlanjutan pembangunan.

Permasalahan lingkungan yang kini dihadapi umat manusia umumnya disebabkan oleh dua hal. Pertama, karena kejadian alam sebagai peristiwa yang harus terjadi sebagai sebuah proses dinamika alam itu sendiri. Kedua, sebagai akibat dari perbuatan manusia. Kedua bentuk kejadian diatas mengakibatkan ketidakseimbangan pada ekosistem dan ketidaknyamanan kehidupan makhluk hidup baik manusia, flora maupun fauna. Ketidakseimbangan dan ketidaknyamanan tersebut dapat dikatakan sebagai bencana. Ali Yafie menyebutnya sebagai kerusakan lingkungan hidup. Bentuk-bentuk kerusakan lingkungan itu berupa pencemaran air, pencemaran tanah, krisis keanekaragaman hayati, kerusakan hutan, kekeringan dan krisis air bersih, pertambangan dan kerusakan lingkungan, pencemaran udara, banjir lumpur dan sebagainya.

Pendekatan ilmu pengetahuan dan teknologi memang diperlukan, akan tetapi itu saja tidak cukup (Kaban, 2007). Masih diperlukan agama untuk terlibat dalam upaya keluar dari krisis lingkungan. Sedangkan Baiquni dan Susilawardani (2002) diperlukan ecospiritual leadership sebagai kunci perbaikan budi pekerti untuk mengelola lingkungan/bumi.

Kaban (2007) mengutik pendapat Mary Evelyn Tucker, seorang guru besar agama dari Bucknel University, mengatakan bahwa agama mempunyai 5 (lima) resep dasar untuk mengurangi kerusakan lingkungan dengan cara lunak, yaitu melalui pendekatan religius. Resep agama dalam penyelamatan lingkungan itu adalah ; Pertama, reference, yaitu keyakinan yang dimiliki oleh para penganut agama yang dapat diperoleh dari teks kitab suci dan kepercayaannya. Kedua, respect, berupa nilai-nilai yang ditanamkan kepada pemeluknya untuk menghargai sesama makhluk hidup. Ketiga, restrain, agama mengajarkan kepada pemeluknya untuk mampu mengelola dan mengontrol sesuatu supaya penggunaannya tidak mubadzir. Keempat, redistribution, agama mengajarkan kepada umatnya untuk mengembangkan kesalehan sosial berupa kemampuan untuk menyebarkan kekayaan, kegembiraan dan kebersamaan melalui langkah kedermawanan kepada sesama makhluk Tuhan. Kelima, responsibility, agama mengajarkan bahwa hidup di dunia ini ada tanggung jawab kepada pencipta dan tanggungjawab dalam merawat kondisi lingkungan.

Bentuk keseriusan berbagai agama di dunia tentang pentingnya kelestarian alam ini dituangkan dalam suatu pernyataan sikap bersama yang terkenal dengan nama "Deklarasi Assisi" yang diprakarsai WWF di Roma pada 1986. Deklarasi tersebut berisi:

"Manusia adalah pengemban amanah,
"berkewajiban" untuk memelihara keutuhan
ciptaanNya, integritas bumi, serta flora dan fauna baik
hidupan liar maupun keadaaan alam asli" (Islam)


"Kami melawan segala bentuk eksploitasi yang menyebabkan kerusakan alam dan yang kemudian mengancam kerusakannya' (Kristiani)

"Kerusakan lingkungan hidup merupakan akibat dari ketidaktaatan, keserakahan dan ketidakpedulian manusia terhadap karunia besar kehidupan"(Budha)

"Kita harus mendeklarasikan sikap kita untuk menghentikan kerusakan, menghidupkan kembali, menghormati tradisi lama kita"(Hindu).

Kemitraan menurut Sulistyani (2004) dilihat dari perspektif etimologis di adaptasi dari kata partnership dan berasal dari akar kata partner. Partner dapat diterjemahkan "pasangan, jodoh atau sekutu". Partnership diterjemahkan menjadi persekutuan atau perkongsian. Kemitraan dapat dimaknai sebagai suatu bentuk persekutuan antara dua pihak atau lebih yang membentuk suatu ikatan kerjasama atas dasar kesepakatan dan rasa saling membutuhkan dalam rangka meningkatkan kapasitas dan kapabilitas di suatu bidang usaha tertentu sehingga dapat memperoleh hasil yang lebih baik.

Kemitraan dapat terbentuk apabila memenuhi persyaratan sebagai berikut: (a) ada dua pihak atau lebih; (b) memiliki kesamaan visi dalam mencapai tujuan; (c) ada kesepakatan; dan (d) saling membutuhkan. Tujuan terjadinya suatu kemitraan adalah untuk mencapai hasil yang lebih baik, dengan saling memberikan manfaat antar pihak yang bermitra.

Tiga pilar utama kemitraan, yaitu masyarakat, pemerintah serta swasta. Seiring dengan perkembangan jaman serta makin luasnya kebutuhan/kepentingan yang harus diwadahi dalam konteks kemitraan, maka swasta yang tadinya hanyalah sebatas pihak yang terkait dengan ekonomi mengalami perluasan. Swasta disini lebih tepat diartikan sebagai pihak-pihak di luar pemerintah dan masyarakat yang mempunyai kepentingan dalam suatu hubungan kemitraan baik yang terkait dengan ekonomi maupun tidak. Dengan perluasan ini, maka pihak-pihak seperti LSM dan perguruan tinggi dan sebagainya yang berperan lebih banyak sebagai fasilitator termasuk salah satu pilar utama dalam kemitraan.

Pesantren, pondok pesantren, atau sering disingkat pondok atau ponpes, adalah sebuah asrama pendidikan tradisional, di mana para siswanya semua tinggal bersama dan belajar di bawah bimbingan guru yang lebih dikenal dengan sebutan Kiai dan mempunyai asrama untuk tempat menginap santri. Santri tersebut berada dalam kompleks yang juga menyediakan masjid untuk beribadah, ruang untuk belajar, dan kegiatan keagamaan lainnya. Kompleks ini biasanya dikelilingi oleh tembok untuk dapat mengawasi keluar masuknya para santri sesuai dengan peraturan yang berlaku (Dhofier, 1983). Terdapat empat elemen dasar sebuah pesantren, yaitu :

1. Kyai. Keberhasilan pesantren banyak bergantung pada keahlian dan kedalaman ilmu, karismatik dan wibawa, serta keterampilan kyai. Dalam konteks ini, pribadi kyai sangat menentukan sebab dia adalah tokoh sentral dalam pesantren (Hasbullah, 1999: 144). Istilah kyai bukan berasal dari bahasa Arab, melainkan dari bahasa Jawa (Ziemek, 1986). Dalam bahasa Jawa, perkataan Kyai dipakai untuk tiga jenis gelar yang berbeda, yaitu 1) sebagai gelar kehormatan bagi barang-barang yang dianggap keramat; contohnya, "kyai garuda kencana" dipakai untuk sebutan kereta emas yang ada di Karaton Yogyakarta; 2) gelar kehormatan bagi orang-orang tua pada umumnya; 3) gelar yang diberikan oleh masyarakat kepada orang ahli agama Islam yang memiliki atau menjadi pimpinan pesantren dan mengajar kitab-kitab Islam klasik kepada para santrinya (Dhofier 1985: 55).

2. Masjid

Sangkut paut pendidikan Islam dan masjid sangat dekat dan erat dalam tradisi Islam di seluruh dunia. Dahulu, kaum muslimin selalu memanfaatkan masjid untuk tempat beribadah dan juga sebagai tempat lembaga pendidikan Islam. Sebagai pusat kehidupan rohani, sosial dan politik dan pendidikan Islam, masjid merupakan aspek kehidupan seharihari yang sangat penting bagi masyarakat. Dalam konteks pesantren, masjid dianggap sebagai "tempat yang paling tepat untuk mendidik para santri, terutama dalam praktek sembahyang lima waktu, khutbah, dan sembahyang Jumat dan pengajaran kitab-kitab Islam klasik (Dhofier, 1985).

3. Santri

Santri merupakan unsur yang penting sekali dalam perkembangan sebuah pesantren karena langkah pertama dalam tahap-tahap membangun pesantren adalah bahwa harus ada murid (santri) yang datang untuk belajar dari seorang alim. Kalau murid sudah menetap di rumah seorang alim, baru seorang alim itu bisa disebut kyai dan mulai membangun fasilitas yang lebih lengkap untuk pondoknya. Santri biasanya terdiri dari dua kelompok, yaitu santri kalong dan santri mukim. Santri kalong merupakan bagian santri yang tidak menetap dalam pondok tetapi pulang ke rumah masing-masing sesudah selesai mengikuti suatu pelajaran di pesantren. Sedangkan santri mukim ialah putera atau puteri yang menetap dalam pondok pesantren dan biasanya berasal dari daerah jauh (Dhofier, 1985).

4. Pondok 
Definisi singkat istilah 'pondok' adalah tempat sederhana yang merupakan tempat tinggal Kyai bersama para santrinya (Hasbullah, 1999). Di Jawa, besarnya pondok tergantung pada jumlah santrinya. Adanya pondok yang sangat kecil dengan jumlah santri kurang dari seratus sampai pondok yang memiliki tanah yang luas dengan jumlah santri lebih dari tiga ribu. Kompleks sebuah pesantren memiliki gedung-gedung selain dari asrama santri dan rumah kyai, termasuk perumahan ustad, gedung madrasah, lapangan olahraga, kantin, koperasi, lahan pertanian dan/atau lahan pertenakan.

Penyebab kerusakan lingkungan seperti disinggung pada latar belakang diatas diantaranya, eksploitasi berlebihan, kesadaran lingkungan rendah, pembangunan berwatak teknokratis dan rente (ekonomi), tuntutan pertumbuhan ekonomi, moral dan perilaku manusia cenderung merusak, kearifan lokal ditinggalkan, jauh dari Tuhan, mengabaikan agama sebagai pendekatan pembangunan. Akibat ini semua mengakibatkan keberlanjutan Indonesia terancam, mengancam kehidupan manusia, kelangkaan dan kerusakan lingkungan hidup, perubahan iklim dan menurunnya daya hidup manusia. Kondisi ini sulit dipecahkan karena menyangkut manusia dan aktivitasnya.

Persoalan lingkungan merupakan masalah global yang memerlukan perhatian para pihak. Untuk mengatasi kerusakan lingkungan memerlukan kesadaran dan kepedulian dari berbagai kelompok masyarakat. Masalah lingkungan tidak mungkin teratasi tanpa adanya pendekatan strategis ditingkat pengambilan kebijakan dan tersediannya solusi-solusi lokal pada tataran pelaksanaan praktis. Pendekatan pengelolaan lingkungan yang dilakukan selama ini seperti pendekatan ekologi, ekonomis, teknologis, sosio-kultural dan sosio-politis tidak menyelesaikan masalah kerusakan lingkungan .

Dalam upaya menumbuhkan semangat pada pemeliharaan planet bumi yang hanya satu-satunya ini, pandangan agama dianggap merupakan faktor penting yang memberikan kontribusi atas sikap manusia terhadap alam dan lingkungan. Mengapa? Ribuan tahun, agama dijadikan sebagai standar kode etik yang sahih dan merupakan warisan tertua kemanusiaan. Kearifan pandangan, kepekaan moral dan sikap religiusitas manusialah yang mungkin dapat menjadi garda penting dan paling akhir yang bisa diharapkan untuk mengingatkan tentang hubungan manusia dalam memelihara alam dan kearifan dalam mengelola bumi . Agama sangat mungkin untuk ikut ambil bagian dalam pelestarian alam dan lingkungan melalui kyai di pondok pesantren.

Pesantren dianggap mempunyai kemampuan dan potensi serta mengakar di masyarakat, antara lain Kyai sebagai pimpinan tidak diganti secara periodik, dan pengaruhnya meluas di daerah sekitarnya. Pesantren dapat menggerakkan banyak anggota masyarakat di perdesaan disekitar pesantren untuk melaksanakan penanaman pohon di kawasan kritis, seperti yang telah lama dilakukan Pesantren Ilmu Giri. Dengan kemampuan ini, timbul keyakinan bahwa memang pondok pesantren dapat berperan sebagai penggerak suatu gerakan konservasi (Gambar 1).

\section{METODE PENELITIAN}

Penelitian ini dilaksanakan di Pesantren Ilmu Giri, Desa Selopamioro, Kecamatan Imogiri, Kabupaten Bantul, Provinsi D.I Yogyakarta (Gambar 2). Data diperoleh dengan cara berbeda-beda sesuai dengan karakteristiknya, termasuk literatur tentang perkembangan Pesantren Ilmu Giri, Imogiri dan lingkup desa kajian. Metode dokumentasi digunakan untuk menggali data-data tentang setting sosial, kondisi lingkungan sebelum dan sesudah berdirinya pesantren, jumlah dan profil kyai dan anggota jamaah/umat binaan, struktur organisasi, publikasi kegiatan pesantren di media massa dan elektronik serta profil lembaga pesantren.

Metode lain adalah wawancara dilakukan sendiri oleh peneliti mulai dari pendirinya, ustad pengasuh jamaah, anggota jamaahnya, petani binaan/warga, dan perangkat desa dan padukuhan. Subjek wawancara dalam penelitian ini disebut dengan informan. Informan lebih ditonjolkan dalam penelitian ini sebagai sumber data. Langkah awal menentukan informan terpilih atau dikenal dengan informan kunci, yaitu informan yang terlibat langsung dengan aktivitas yang diteliti. Metode penentuan informan yang akan di wawancara menggunakan cara snowball untuk mendapatkan informasi berkaitan dengan kebutuhan data yang diperlukan. Wawancara mendalam kepada informan terpilih yang digali berdasarkan panduan wawancara dengan alat bantu rekam. Materi panduan wawancara digunakan sebagai alat kontrol peneliti saat wawancara agar pertanyaan yang diajukan tidak melenceng dari permasalahan dan tujuan penelitian. Untuk memperoleh informasi mendalam melalui kyai, peneliti seringkali mengikuti setiap kegiatan di pesantren.

Kemudian untuk dapat memahami tradisi mereka berkaitan dengan ajaran dan amalan eco religi jamaah Pesantren Ilmu Giri, peneliti mengikuti kegiatan mereka, seperti mujahadah rutin malam Selasa Pon, 
pengajian jamaah, festival anak yatim dan lain-lain. Peneliti live in (tinggal) di lokasi penelitian untuk memahami aktivitas mereka. Peneliti menggunakan pengamatan partisipatif pada setiap kesempatan. Metode pengamatan partisipatif dikombinasikan dengan Focus Group Discussion untuk menemukan perbedaan-perbedaan pandangan diantara mereka. Pengamatan partisipatif untuk mendeskripsikan setting yang dipelajari, aktivitas-aktivitas yang berlangsung, orang-orang yang terlibat dalam aktivitas, dan makna kejadian di lihat dari perpektif mereka yang terlihat dalam kejadian yang diamati tersebut.

Data sekunder dalam penelitian ini merupakan data yang diperoleh dari instansi-instansi terkait, seperti profil wilayah penelitian (kabupaten, kecamatan, desa dan dusun), RTRW, serta berbagai pustaka, kliping koran, jurnal, dan laporan-laporan penelitian yang berhubungan dengan judul penelitian.

Setelah data-data terkumpul melalui wawancara, observasi, FGD, dokumentasi dan analisis selanjutnya data dicatat secara deskriptif lalu dianalisis secara kualitatif. Ringkasnya, semua data yang dikumpulkan kemudian dideskripsi, diklasifikasi, interpretasi dan dianalisis sesuai dengan topik, sub-sub tema dari kerangka seluruh isi tesis sejak penelitian lapangan hingga selesainya penulisan. Data yang terkumpul lalu dianalisis secara deskriptif kualitatif. Secara sederhana gambar diagram alur penelitian (Gambar 3).

\section{HASIL DAN PEMBAHASAN}

Desa Selopamioro terletak di perbukitan Kabupaten Bantul merupakan kawasan tandus dan kering, masuk dalam kawasan Gunung Sewu. Selopamioro memiliki pemandangan yang indah, dengan tebing-tebing dari pegunungan kapur dan dilintasi oleh Sungai Oyo. Secara fisik, Desa Selopamioro memiliki tiga bentuk wilayah, yaitu (a) datar sampai berombak sebesar 10\%; (b) berombak sampai berbukit sebesar 15\% dan; (c) berbukit sampai dengan bergunung 75\%. Secara biotis lahan pekarangan masih luas dan banyak ditanami dengan tanaman produktif (pangan, palawija, buah, sayur) dan tanaman keras/jangka panjang. Secara sosial budaya, Desa Selopamioro memiliki nuansa adat dan tradisi berbasis pertanian dengan kepercayaan tradisional yang masih cukup kuat. Perbedaan mencolok adalah kehadiran pesantren yang telah memberikan perubahan fisik, biotik dan sosial budaya di wilayah ini.

Pesantren Ilmu Giri beberapa tahun terakhir tidak henti-hentinya menjadi sorotan media elektronik dan cetak. Pasalnya di atas tanah perbukitan yang terpencil, jauh dari keramaian dan hiruk pikuk kota, diantara rerimbunan pohon jati itu berdiri sebuah institusi pendidikan Pesantren Ilmu Giri. Telah banyak para tokoh baik budayawan, pejabat negara, seniman, penyair, akademisi dan spiritualis yang datang untuk membuktikan betapa pesantren ini merupakan sebuah obyek baru yang bernuansa pendidikan, lingkungan dan keagamaan.

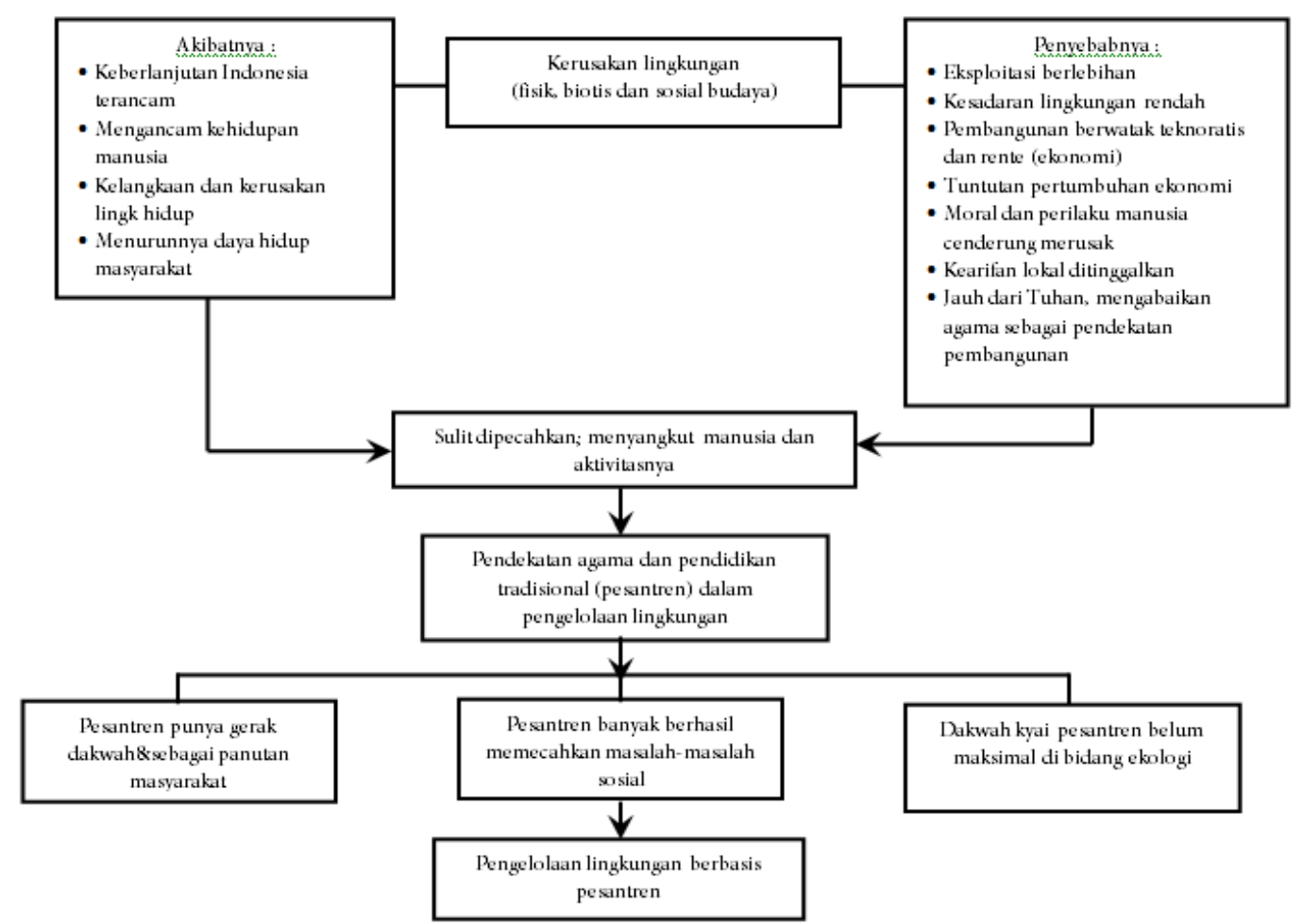

Gambar 1. Kerangka Penelitian 


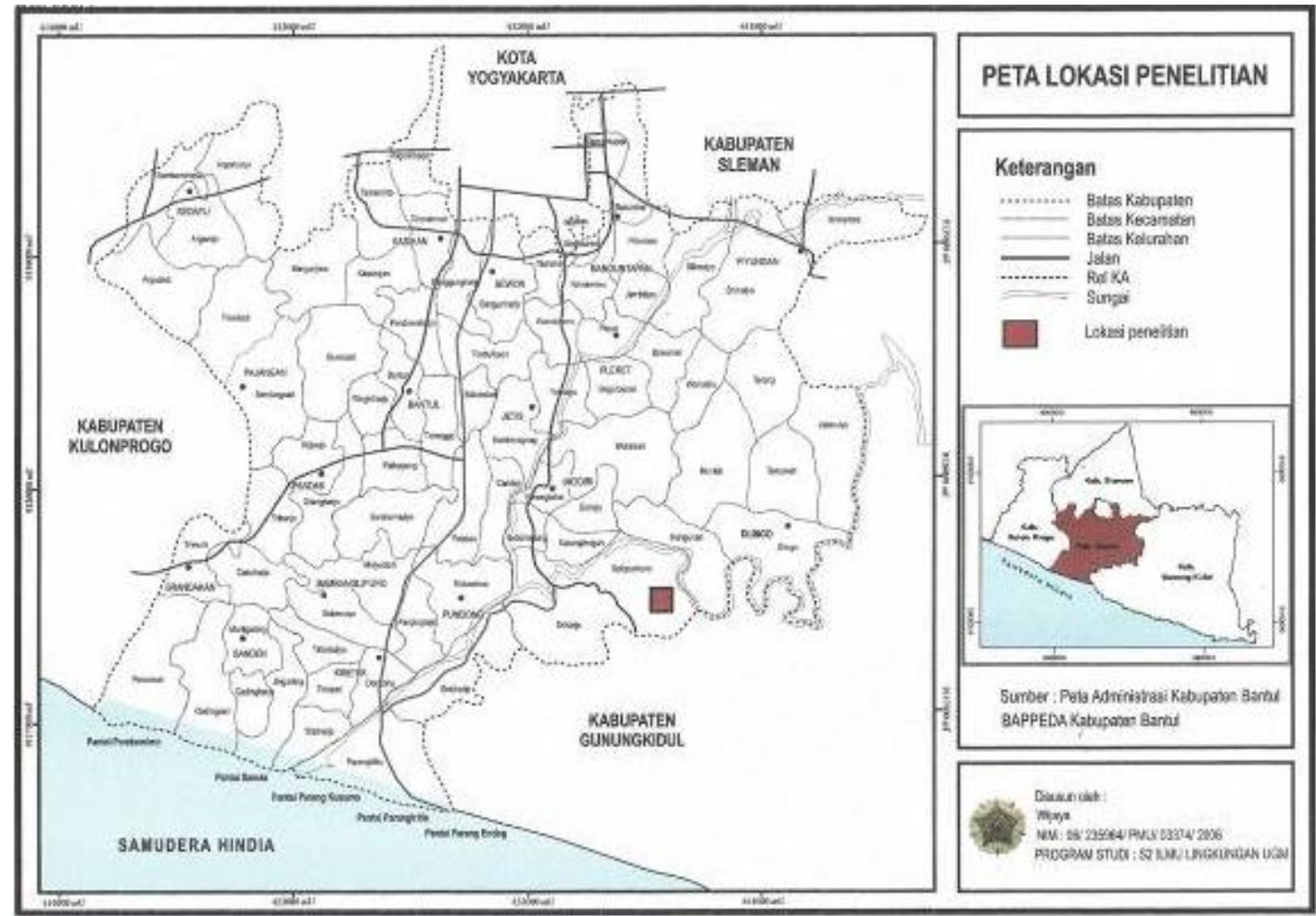

Gambar 2. Peta Lokasi Penelitian

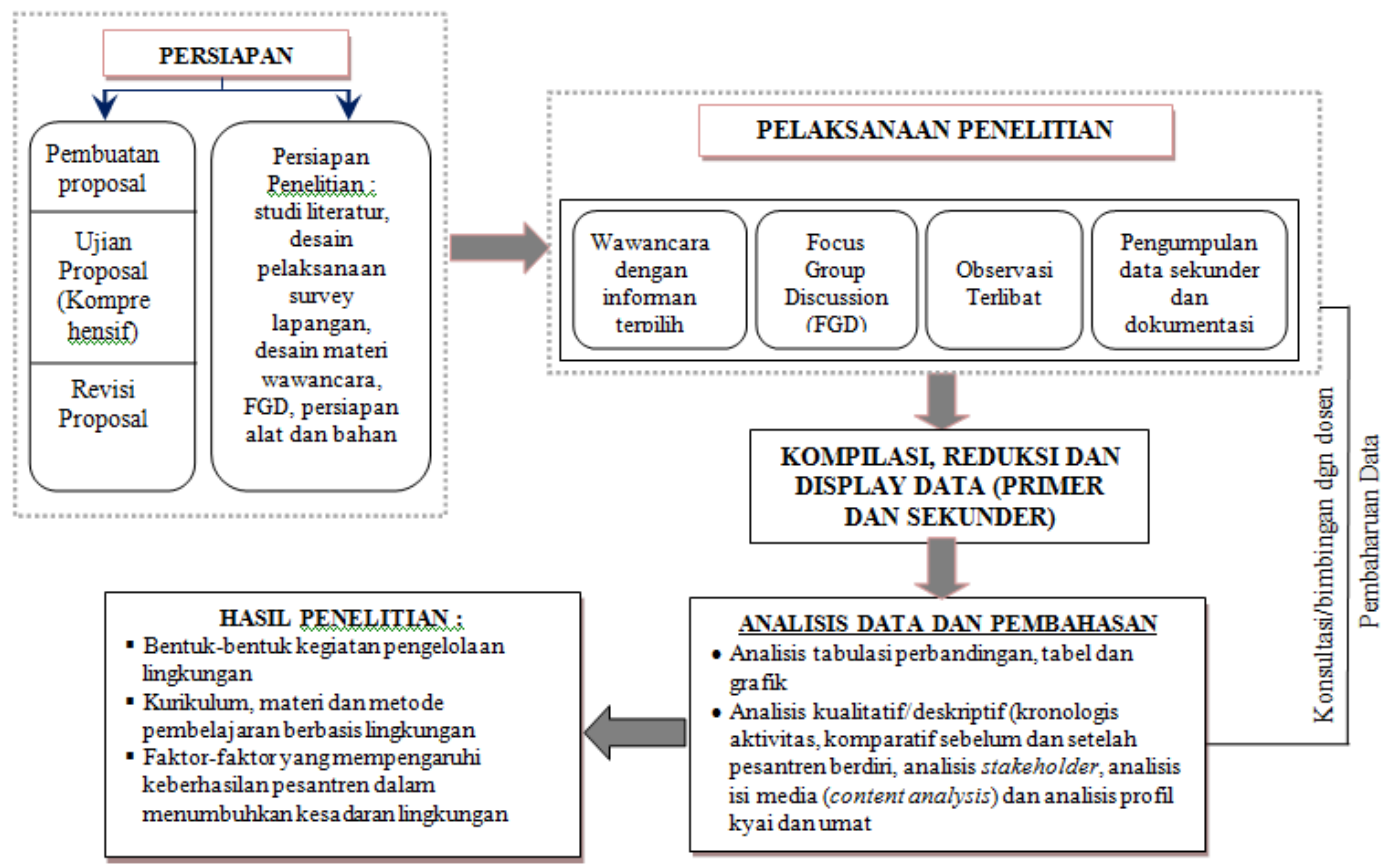

Gambar 3. Diagram Alur Penelitian

Pesantren Ilmu Giri memiliki nuansa alami dan budaya yang berbeda dari pesantren lainnya. Bagi siapa yang berkunjung ke tempat ini akan langsung disapa oleh pemandangan alam-nya, pohon-pohon besar yang rindang diantara beberapa bangunan khas Jawa begitu menyejukkan mata dan hati. Di lereng-lereng gunung itulah masyarakat kembali menggarap tanah warisan. Ahli waris yang baik tidak boleh membiarkan tanah warisan para pahlawan menjadi lahan tidur yang tidak produktif.
Lebih jauh, Pesantren Ilmu Giri memiliki sesuatu hal yang sinergis dengan ke-asrian alamnya, yaitu konservasi budaya yang memiliki ruh "aktivitas manusia" dalam lingkaran kearifan budaya masyarakat, spirit pemberdayaan lingkungan dan transformasi nilai-nilai religiusitas. Hal diatas merupakan penjabaran visi-misi Pesantren Ilmu Giri: "Bagaimana menciptakan satu ruang yang dapat memadumadankan nilai-nilai "religius" (Islam) dengan perkembangan zaman, karena nilai-nilai religiusitas http://jurnal.ugm.ac.id/mgi | 86 
yang "mem-bumi" dan mampu meretas segala perbedaan ke dalam kearifan adalah tonggak kehidupan manusia (Wawancara dengan KH. Nasruddin Anshoriy, 23 September 2014).

Sejak sebelas tahun berdiri, Pesantren Ilmu Giri telah mampu membangun dan mengembangkan konstruksi-keberadaannya sebagai "subyek-kehidupan", yaitu "ruang-keseimbangan" antara "nature-wisdom", perilaku manusia dan nilai religius dalam lantunan "gerak-kebudayaan". Wujud nyata dari hal tersebut terangkum dalam berbagai kegiatan "Cultural-Activity" (Anshoriy, 2014). Berikut ini gambaran bentuk-bentuk kegiatan pengelolaan lingkungan hasil kemitraan Pesantren Ilmu Giri dengan masyarakat.

\section{Penghijauan melalui hutan santri dengan Konsep Eco- Religi}

Salah satu model hutan rakyat yang dikembangkan oleh Pesantren Ilmu Giri adalah hutan santri. Hutan santri yang dalam konteks Pesantren Ilmu Giri adalah hutan yang pengelolaannya melibatkan masyarakat dusun Nogosari dengan dimotori oleh Pesantren Ilmu Giri, seluas 50 ha yang tersebar sebagian besar di Dusun Nogosari dan sebagian kecil tersebar di Dusun Nawungan dan Dusun Kedung Jati, Desa Selopamioro, Kecamatan Imogiri, Kabupaten Bantul.

Hutan santri yang dikelola oleh kemitraan antara Pesantren Ilmu Giri dan masyarakat di tiga dusun Desa Selopamioro ini termasuk dalam kelompok Hutan Rakyat. Hutan santri dicetuskan pada tahun 2005, hingga kini telah mencapai luas 55 hektar dengan 126 anggota. Semula lahan tersebut hanya 25 hektar, yang terdiri dari akumulasi lahan pesantren seluas 7 hektar dan 38 hektar selebihnya milik masyarakat. Tanaman yang khusus ditanam di hutan santri Ilmu Giri adalah pohon Jati (Tectona grandis) sekitar 70\%, 10\% mahoni (Swietenia mahagoni), 10\% Cendana (Santalum album) dan $10 \%$ tanaman buah dan sonokeling. Dinamakan hutan santri karena, (a) dikelola oleh santri atau jamaah Pesantren Ilmu Giri; (b) digunakan untuk kepentingan santri baik berkaitan dengan fungsi hutan, yaitu keteduhan/sejuk, ketersediaan air, ekonomi, eksistensi diri dan masyarakat dan pasar ide.

Seperti pada konsep dalam pembangunan dan pengelolaan hutan rakyat, hutan santri memiliki fungsi seperti hutan rakyat pada umumnya, yaitu meliputi fungsi ekologis, sosial, ekonomi, perlindungan dan fungsi keindahan. Namun, ada hal berbeda yang terdapat dalam hutan santri yang tidak ditemukan pada hutan rakyat kebanyakan. Metode pengelolaan hutan santri hampir sama dengan hutan rakyat, namun lebih berlandaskan pada nilai spiritualitas agama berdasarkan pada pemenuhan kebutuhan ekonomi dan kearifan lokal masyarakat (Sudrajat, 2011).
Perbedaan yang lain dalam pengelolaan hutan santri adalah tujuan pengelolaan hutan yang ingin dicapai. Menurut UU Nomor 41 tahun 1999 tentang Kehutanan, tujuan pengelolaan hutan adalah konservasi, fungsi lindung, dan fungsi produksi untuk mencapai manfaat lingkungan, sosial, budaya dan ekonomi yang seimbang dan lestari, sedangkan tujuan pengelolaan hutan santri adalah untuk melestarikan alam sesuai dengan amanah agama sekaligus memberdayakan penduduk lokal dalam segi ekonomisnya. Hal ini ternyata mampu dilakukan bersama dan berkesinambungan dalam pengelolaan hutan dan lahan di dusun Nogosari.

Basis pengelolaan pada penyelamatan lingkungan yang dirintis di hutan santri adalah dengan berbasiskan pada nilai-nilai spiritualitas agama dan kearifan lokal penduduk di dusun Nogosari. Hal ini dilakukan karena dipandang sudah saatnya pengelolaan hutan harus selaras dengan nilai agama dan kearifan lokal yang ada, sehingga ajaran agama tidak hanya menjadi dogma dan teori saja, namun dapat diterapkan dalam kehidupan masyarakat. Dengan pemahaman yang komprehensif kepada masyarakat terkait konsep ini, diharapkan dapat tercapai model pengelolaan hutan di Indonesia yang lebih baik kedepannya agar kelestarian hutan di Indonesia terjaga dan dapat diwariskan kepada generasi penerus selanjutnya (Anshoriy, 2014).

Konsep yang dikembangkan oleh Pesantren Ilmu Giri dalam pengelolaan hutan santri sebagaimana dikemukakan oleh KH. Nasruddin Anshoriy Ch :

"Dengan membangun basis mental dan teologi yang benar, bahwa tugas kekhalifaan manusia adalah selain untuk menyembah pada Allah dan mensyukuri karunia Illahi juga adalah dengan cara memakmurkan bumi. Maka para santri yang berbasis di akar rumput tersebut melalui konsep dan teologi amanahnya akan mampu menjaga, merawat, dan mengelola hutan dengan sebaik-baiknya. Firman Allah SWT dalam Alquran yang menyeruh manusia beriman untuk memakmurkan bumi jelas merupakan landasan teologi yang sangat relevan untuk terus menerus dikumandangkan. Begitu juga sabda Rasulullah Muhammada SAW yang menyebutkan "seandainya besok pagi terjadi kiamat, maka akan tetap aku tanam biji kurma pada hari ini" begitu jelas menggambarkan bahwa agama Islam begitu tinggi menjunjung pelestarian alam, perawatan lingkungan, pemeliharaan hutan, dan bukanya justru mengeksploitasi untuk kepentingan pribadi.

Pembangunan hutan santri bersamaan dengan pendirian Pesantren Ilmu Giri yang dipimpin oleh $\mathrm{KH}$. Nasruddin Anshoriy Ch sebagai pendiri utamanya, yaitu dimulai pada tahun 2003 dengan prioritas utama 
adalah membuat dan menyalurkan air bersih dari dusun Kedung Jati ke dusun Nogosari . Sebelumnya, sebagai daerah yang kering dan tandus sangat sulit memperoleh air bersih. Air adalah komoditas mahal dan berharga yang sulit diperoleh masyarakat dusun Nogosari. Air inilah yang diharapkan sebagai peretas kemakmuran dan kesejahteraan warga sehingga pembinaan yang dilakukan dapat berjalan dengan lancar.

Pohon merupakan makhluk yang paling dirahmati sejak diciptakan, karena pohon adalah makhluk yang paling bisa menerima tanpa meminta. Dia memberikan segala yang dimilikinya untuk memberikan manfaat kepada manusia, binatang dan alam. Untuk mendukung penjelasannya tersebut, KH. Nasruddin Anshoriy Ch menggunakan dalil-dalil dari kitab suci al-Qur'an dan Hadist sebagai pegangan orang-orang Islam. Seperti ciptaan Allah yang lain, pohon merupakan makhluk yang tak henti-hentinya bersujud dan bertasbih padaNya sesuai dengan firman Allah dalam surah Al Hajj:18 sebagai berikut:

"Apakah kamu tiada mengetahui bahwa kepada Allah bersujud apa yang ada di langit dan di bumi; langit, matahari, bulan, bintang, gunung, pohonpohonan, binatang-binatang melata dan sebagian besar dari manusia?”.

Disebutkan juga dalam QS. Ar Rahman 6: "Dan tumbuh-tumbuhan dan pohon-pohonan, keduanya tunduk kepadaNya". Juga dijelaskan dalam hadist, Tidaklah seorang muslim yang menanam pohon atau yang mananam tanaman yang kemudian hasilnya dimakan burung, manusia atau binatang, melainkan hal itu bagi penanam itu menjadi sedekah (HR. Bukhori).

Dalam kegiatan bermasyarakat seperti pengajian dan penyuluhan yang dilakukan, juga dijelaskan bahwa banyak manfaat (pahala) yang didapatkan dari menanam pohon selain manfaat ekonomis. Dijelaskan bahwa, daun-daun atau biji-biji yang gugur dari pohon tersebut akan dimakan oleh burung atau binatang lainnya, atau sekedar dijadikan rumah atau sarang binatang sebagai tempat berlindung. Dengan memberi ruang bagi mahkluk Tuhan, maka semua itu adalah menjadi pahala sedekah bagi sang penanam. Dengan konsep seperti ini, warga masyarakat yang mayoritas beragama Islam diharapkan tertarik dan terlibat serta.

Diceritakan oleh KH. Nasruddin Anshoriy Ch bagaimana pernikahan tersebut akan begitu bermakna dengan mahar pohon Jati tersebut. Pernikahan yang didasari cinta yang tulus akan mendapat rahmat dari Sang Pencipta, dengan syari'at yang sudah ditetapkan. Saat ijab qabul berlangsung, pasangan pengantin akan disaksikan oleh para malaikat atas perintah Allah (hablumminallah), disaksikan para manusia yang hadir (hablumminannas) dan juga disaksikan oleh alam, yaitu pohon yang dijadikan sebagai mas kawin (hablumminal alamin). Seluruh saksi berdoa untuk mempelai agar selalu dilimpahkan rahmat dan ridha-Nya.

Selain itu, gagasan baru yang juga diberikan adalah melalui media pernikahan, khususnya pernikahan secara Islam. Dalam pernikahan, selalu diadakan mahar perkawinan sebagai salah satu syarat wajib dan sahnya sebuah pernikahan. Kepada warga masyarakat yang akan menikah, disarankan untuk menyediakan bibit pohon sebagai mahar pernikahan di samping mahar-mahar yang lainnya. Mahar berupa bibit pohon tersebut dijelaskan sebagai investasi masa depan bagi pasangan pengantin dan keturunannya.

Masih menurut KH. Nasruddin Anshory Ch dijelaskan apabila mempelai pria menyediakan mahar perkawinan berupa bibit pohon jati sebanyak 40 pohon. Dari 40 pohon tersebut kemudian tumbuh seiring bertambah waktu dan lahirnya anak-anak mereka yang tidak terasa menjadi investasi untuk kehidupan selanjutnya. Dalam konsep investasi, dijelaskan bahwa hingga anaknya remaja dan mencapai usia 14 tahun dan sudah duduk di bangku kelas 1 Sekolah Menengah Pertama (SMP), pohon Jati tersebut telah besar dan kira-kira bernilai ekonomis \pm Rp1.000.000,- setiap pohon. Jadi jika di hitung, Rp1.000.000,- x 40 pohon $=$ Rp40.000.000,-. Dengan demikian, seorang siswa/siswi SMP akan mempunyai investasi kurang lebih sebesar Rp40.000.000,-.

Kemudian, pada usia 17 tahun, setiap pohon kirakira akan berharga Rp2.500.000,- dikalikan 40 pohon maka investasi yang ada kurang lebih Rp100.000.000,-. Maka, diperkirakan pada saat anak usia SMA telah mempunyai investasi sebesar Rp100.000.000-. Pohon investasi tersebut dapat digunakan untuk membiayai biaya pendidikannya sampai perguruan tinggi dan juga memenuhi kebutuhan ekonomi keluarga. Selain penjelasan bahwa pohon tersebut dapat digunakan sebagai investasi ekonomi dan agama, model mahar pernikahan berupa pohon tersebut juga merupakan salah satu bukti bahwa masyarakat Desa Selopamioro telah berpartisipasi dalam penyelamatan lingkungan esuai dengan program pemerintah.

Strategi dan pola pemberdayaan masyarakat yang dilaksanakan Pesantren Ilmu Giri yang mempunyai visi misi berpikir, berdzikir dan bekerja adalah merencanakan dan mengupayakan dengan sungguhsungguh untuk menjadikan pesantren ini sebagai pusat pendidikan dan pembelajaran masyarakat yang diangkat dari nilai-nilai tradisionalnya, yaitu mengelola alam dan budaya. 
Pesantren Ilmu Giri dalam perjalanannya mampu melestarikan dan mengangkat budaya dan tradisi lokal Desa Selopamioro. Pesantren Ilmu Giri memiliki kekhasan yang tidak dimiliki pesantren pada umumnya, sebab Kyai Nasruddin memberi nama pesantren budaya, dimana visi dan misinya adalah konservasi pelestarian budaya hingga tradisi masyarakat lokal. Kehadiran pesantren ini berakar pada budaya masyarakat dengan mengembangkan event-event budaya dan tradisi Jawa, pengembangan potensi seni musik religi tradisonal, seperti group shalawatan, jathilan, wayang wong, gejok lesung, teater rakyat dan musik hadrah, group dangdut tradisional dan lain sebagainya yang secara rutin ditampilkan disela acara mujahadah dan hari-hari besar Islam.

Sebelum berdirinya Pesantren Ilmu Giri, kehidupan masyarakat dusun Nogosari tergolong terbelakang atau bisa dikatakan masih berada dalam lingkaran kemiskinan. Dahulu masyarakat pada musim tanam sangat sulit untuk memperoleh bibit dan pupuk, sementara kebutuhan pupuk dan bibit cukup tinggi sekitar 7-8 ton untuk wilayah Nogosari. Kondisi sulit, terbelakang dan sangat jauh dari kota ini memaksa masyarakat harus membeli bibit dan pupuk kepada pihak-pihak yang memiliki modal (tengkulak) di luar wilayah Desa Selopamioro dengan harga yang tinggi. Sistem yang dikembangkan oleh tengkulak tersebut dilakukan dengan memfasilitasi kebutuhan pupuk dan bibit yang dibutuhkan masyarakat dengan harga selangit. Para tengkulak juga seringkali meminjamkan modal kepada masyarakat yang tidak memiliki kemampuan finansial untuk bercocok tanam dengan persyaratan pembayaran dilakukan setelah panen dengan perjanjian petani hanya boleh menjual hasil panen khusus kepada tengkulak tersebut. Ringkasnya, harga panen ditingkat petani dikuasai dan dimainkan sepenuhnya sesuai keinginan tengkulak. Kondisi inilah letak "penderitaan" petani dusun Nogosari selama kurang lebih 10 tahun.

Berawal dari masalah permainan tengkulak yang menimpah petani dusun Nogosari, maka Pesantren Ilmu Giri yang baru saja berdiri saat itu berinisiatif mendirikan lembaga keuangan desa yang berbasis syariah yang diberi nama Lembaga Keuangan Mikro BMT Talang Emas. Lembaga ini berdiri pada tanggal 14 November 2005 hasil kerjasama dengan lembaga Pusat Inkubasi Bisnis Usaha Kecil (PINBUK) DIY dengan menempatkan masyarakat dusun Nogosari sebagai subjek pemberdayaan dan pelaku. Tujuan dari pendirian BMT Talang Emas ini adalah peningkatan kesejahteraan masyarakat dusun Nogosari dan sekitarnya dari peningkatan hasil-hasil pertanian mereka.
Peran BMT Talang Emas sebagai pemberi modal terhadap kebutuhan masyarakat, baik untuk modal bertani-bercocok tanam dan perdagangan (membuka dan mengembangkan usaha). Produk-produk pembiayaan BMT Talang Emas dikhususkan pada pembiayaan pertanian dengan konsep Murabahah (jual beli). Konsep jual beli yang dikembangkan Talang Emas adalah bertindak sebagai penjual, sementara nasabah dalam hal ini petani sebagai pembeli. Barang dan jasa yang diperjualkan dalam produk pembiayaan murabahah adalah bibit, pupuk dan pemberian modal dana segar kepada nasabah untuk investasi, seperti membeli kerbau atau sapi untuk membajak sawah, membayar pajak tanah serta membayar buruh tani bagi penggarap sawah. Harga jual bibit, pupuk dan pemberian modal (dana cair) kepada nasabah adalah harga beli BMT Talang Emas dari pemasok ditambah keuntungan (margin). Hingga kini omset simpan pinjam BMT Talang Emas telah mencapai \pm Rp500 juta lebih . Berdirinya Pesantren Ilmu Giri membawa banyak perubahan yang sangat signifikan terhadap kemajuan desa dan padukuhan Nogosari, berbagai aspek kehidupan masyarakat berubah ke arah lebih baik. Salah satunya pada aspek ekonomi masyarakat, dimana masyarakat telah mampu menggali potensi sumberdaya manusia yang ada untuk memanfaatkan potensi sumber daya alam yang terdapat di dusun Nogosari. Tabel 1 menggambarkan komparasi kondisi lingkungan sebelum dan sesudah berdirinya Pesantren Ilmu Giri.

Pesantren Ilmu Giri memiliki beragam sumberdaya pangan berupa makanan tradisional yang dibudidayakan oleh petani dusun Nogosari, seperti ubi jalar, pisang, kelapa, talas, singkong (ubi kayu), jagung, sayur-sayuran dan aneka buah-buahan. Makanan ini sangat mudah diperoleh di lahan warga dan memiliki harga yang lebih murah dibanding makanan barat.

Oleh karena itu, Pesantren Ilmu Giri dengan konsep pemberdayaan masyarakat lokal yang digagasnya mengkampanyekan makanan organik yang halal tanpa pemanis, pengawet dan pewarna, yang kesemuannya bisa ditemukan sekitar pesantren, seperti ubi, singkong, jagung, pisang, kelapa serta aneka buah yang sengaja ditanam disana. Alam sekitar telah memberikan makanan sehat yang melimpah pada kita, kenapa kita bunuh diri dengan makanan sampah beracun dan alkohol dari negara kapitalis (Anshoriy, 2014).

Semua hal ini dilakukan dengan konsep pelestarian lingkungan alam dan budaya serta tradisi masyarakat dengan konsep taman pembelajaran bagi semua warga masyarakat, dari usia dini hingga lanjut usia. Semakin tingginya kesadaran masyarakat akan kebutuhan 
hidup sehat dan munculnya berbagai penyakit baru telah memicu berbagai produksi bahan makanan kembali menggunakan proses alami atau 'back to nature'. Singkatnya, kearifan lokal yang sudah mulai terkikis diangkat kembali dengan konsep kembali ke alam oleh Pesantren Ilmu Giri.

Kampanye makanan sehat ini sejalan dengan respons atas tingginya bahaya polusi maupun hal-hal yang berbau kimiawi, mengundang sebagian orang untuk mulai menyadari pola hidup sehat. Salah satunya, dengan mengonsumsi makanan organik, yakni bahan makanan yang bebas bahan kimia dan pestisida. Banyak kalangan akhir-akhir ini telah mengikuti tren positif makanan organik ini. Memilih makanan organik ini bila dilihat dari segi nutrisi, ternyata mengandung kandungan gizi lebih baik dibandingkan dengan bahan pangan non-organik ala barat. Makanan organik berbasis budidaya oleh petani dari pupuk alami, secara medis berarti lebih membantu proses pertumbuhan dan perbaikan tubuh bila mengalami masalah.

Pesantren Ilmu Giri didirikan dalam rangka mengantisipasi maraknya kerusakan lingkungan dengan selalu melandasi diri pada ajaran agama. Pesantren Ilmu Giri telah membimbing masyarakat dari orang dewasa sampai ke anak-anak untuk meningkatkan kualitas diri dengan tidak meninggalkan lingkungannya. Dalam konteks pendidikan istilah kurikulum tak dikenal di Pesantren Ilmu Giri karena pesantren ini mengikuti pola salafi (tradisional) berbeda konsep dengan pesantren pada umumnya yang memiliki santri dan pondokan. Pesantren Ilmu Giri hanya memiliki jamaah binaan warga (mayoritas orangtua) yang bergabung dalam sebuah komunitas yang disebut jamaah mujahadah sejumlah \pm 450 jamaah dari 3 dusun serta santri Taman Pendidikan Al-Qur'an (TPA) sejumlah \pm 100 anak. Jamaah mujahadah inilah yang menjadi santri dan sasaran dakwah pengasuh. Materi dan metode pembelajaran di pesantren diarahkan pada etika lingkungan dan pemberdayaan masyarakat dalam rangka mencapai visi Pesantren Ilmu Giri seperti yang telah disinggung diatas.

Untuk materi TPA dikembangkan konsep pembelajaran berbasis sekolah alam juga menjadi alternatif penyelamatan lingkungan. Diharapkan dengan sekolah alam ini dapat mengarahkan pola budaya hidup peserta didik pada kepedulian terhadap lingkungan hidup. Melalui sekolah alam diharapkan dapat membuka pemahaman peserta didik tentang lingkungan yang secara substansial terfokus pada kesadaran akan makna eco-spiritualitas. Aspek-aspek pendidikan lingkungan yang mencakup pengetahuan lingkungan secara umum, internalisasi nilai-nilai penyelamatan lingkungan dan pencarian pola-pola aksi penyelamatan lingkungan, melalui pelatihan ekonomi lingkungan yang disistematisasi lebih jauh ke dalam sebuah ceruk (niche) yang spesifik, yaitu ecospiritualitas lingkungan yang inherent dalam dinamika komunitas lokal.

Inti pengajaran santri adalah menanamkan pengetahuan dan kearifan dalam hidup mereka, selain mempelajari al-Quran. Materi pengajaran berbasis alam sekitar pesantren, khususnya alam hutan dan budaya tradisi. Santri diajarkan mengenal pohon, kayu, batu, satwa/binatang untuk digali asal muasalnya dan manfaatnya. Targetnya setelah mereka keluar dari pesantren, maka akan muncul pemuda-pemuda yang paham agama, tetapi juga perduli pada lingkungan alam dan budaya tradisi.

TPA Pesantren Ilmu Giri merupakan lembaga pendidikan yang dalam kegiatan belajar mengajarnya memberikan bekal pengetahuan keagamaan bagi santri/peserta didiknya disamping pengetahuan umum lainnya. TPA selama ini dibina oleh tokoh-tokoh agama Islam/Ustad dan Ustadzah di lingkungan Desa Selopamioro. Dalam upaya meningkatkan kualitasnya TPA selalu bekerjasama dengan masyarakat dan pihak pemerintahan setempat untuk mencapai tujuan pendidikan yang baik. Dalam mendidik para santri, Kyai Nasruddin dibantu oleh pengasuh lainnya, diantaranya Ustadz Mujiono dan Ustad Faqih. Para pengasuh dan pengajar santri ini memiliki bidang tugas dan kewenangan masing-masing.

Kegiatan pengajian santriwan-santriwati Pesantren Ilmu Giri mengusung konsep pelestarian lingkungan dan pengembangan berbagai budaya dan tradisi masyarakat dengan konsep taman pembelajaran bagi semua warga masyarakat, dari usia dini hingga usia lanjut. Diantara kekhasan pesantren ini yang tidak dipunyai oleh institusi pesantren pada umumnya adalah untuk memberbadayakan dan mencetak generasi relegius, para santri dibimbing dengan memanfaatkan kekayaan alam sekitar.

Menurut KH. Nasruddin Anshoriy Ch terdapat enam konsep materi pengajaran yang diberikan pada jamaah mujahadah Ilmu Giri : (a) konsep tentang Kehidupan; (b) konsep Hubungan Segitiga : Allah, Manusia dan Alam; (c) Arafah : Ideal Koneksitas; (d) transformasi 'Abd Allah kepada Khalifah Allah; (e) alam : Sumber Ma'rifat Allah; (f) kehampaan spiritual : biang kerusakan Lingkungan. 
Tabel 1. Komparasi Kondisi Lingkungan Sebelum dan Sesudah Masuknya Pesantren

\begin{tabular}{ccr}
\hline \multirow{2}{*}{ No } & \multicolumn{2}{c}{ Kondisi Lingkungan (Fisik, Sosial dan Budaya) } \\
& Sebelum Berdirinya Pesantren & Sesudah Berdirinya Pesantren \\
\hline
\end{tabular}

1. Lahan tandus, kering dan terjal berbukit Lahan (tanah) milik warga menjadi hijau dengan tanaman keras/jangka panjang, palawija, buah, sayur. Penghijauan dengan model hutan santri seluas 55 hektar tersebar 3 dusun dengan

2. Kesulitan air bersih

3. Kesulitan bibit dan pupuk di tingkat petani

4. Kampung terisolasi belum tersentuh jalan aspal

5. Kesenjangan sosial

(kesulitan modal untuk pengembangan usaha)

6. Pendidikan rendah/terbatas (maksimal hanya tamatan SLTP)

7. Kemampuan baca tulis Alquran tinggi

8. Budaya dan tradisi tidak muncul

9. Pemahaman masyarakat/warga terhadap agama dan pelestarian alam rendah

10. Makanan tradisional belum dimanfaatkan maksimal anggota 126 petani.

Pesantren berinisiasi pengadaan air bersih dengan sumur pompa Inisiasi berdirinya LKM BMT Talang Emas yang sebagai pemberi bantuan modal bertani-bercocok tanam dan perdagangan

- Pesantren membuka isolasi wilayah kemitraan dengan masyarakat

- Jalan raya aspal masuk kampung dan menghubungkan antar dusun dan desa

- Listrik telah tersambung, awalnya hanya di lokasi pesantren.

- Desa Selopamioro mulai dikenal masyarakat karena ekspose media atas kegiatan pesantren

- Mulai ramai dengan aktivitas pesantren

- Desa Selopamioro dan Pesantren Ilmu Giri banyak dikunjungi pejabat pusat, daerah, seniman/artis, aktivitas keagamaan dan akademisi

- Lokasi pertemuan mahasiswa lintas agama

- Dicanangkan sebagai Desa Kebangsaan oleh Kementerian Sosial Tahun 2008

- Ternak sapi dan kambing kemitraan pesantren dan masyarakat

- Inisiasi berdirinya LKM BMT Talang Emas yang sebagai pemberi bantuan modal bertani-bercocok tanam dan perdagangan

Saat ini sekitar 212 orang telah menempuh kuliah di perguruan tinggi baik jenjang diploma maupun sarjana

Berdiri Tempat Pengajian Alquran (TPA) di pesantren dengan santri \pm 100 anak dari Desa Selopamioro.

Digali dan dikembangkan oleh Pesantren Ilmu Giri. Pengembangan budaya dan tradisi lokal menjadi agenda pemberdayaan pesantren (gejok lesung, gamelan, jatilan, wayang, reog, musik religi, wiwit, angler, supitan, mitoni, dll.

Kegiatan mujahadah diikuti oleh jamaah pesantren meningkatkan pemahaman agama dan menumbuhkan kesadaran lingkungan.

Pesantren memberikan pemahaman bahwa banyak manfaat pahala yang diperoleh dari menanam pohon selain manfaat ekonomi Pesantren Ilmu Giri mengkampanyekan makanan tradisional hasil kebun petani yang halal, tanpa pemanis, pengawet dan tanpa pewarna dan menolak penggunaan pupuk kimia. Pesantren tidak hanya mengkampanyekan, namun juga dipraktekan pada setiap tamu yang berkunjung disuguhkan makanan ala kampung seperti pisang/kacang rebus, jagung, singkong rebus, kacang rebus, tiwul, sayur-sayuran

Sumber : Hasil analisis, 2014

Konsep etika lingkungan dengan manusia sebagai subjek agar tidak merusak alam selalu menjadi bahan pengajaran Pesantren Ilmu Giri kepada komunitasnya baik jamaah mujahadah, santri maupun kepada masyarakat secara luas. Merealisasikan fungsi kekhalifaan manusia yang dicintai Tuhan dengan mengambil segmen pelestarian lingkungan alam, budaya dan ekonomi sebagai gerakan pemberdayaa Dalam konteks ini, pengembangan kreativitas santri sebagai pengamalan dari makna ayat al-Qur'an "fastabiqu al-khairat" (berlomba-lomba dalam kebaikan) sangat besar pengaruhnya pada peningkatan pendidikan. Para santri harus menyadari status dirinya sebagai khalifatullah yang membawa konsekwensi akan 
tugas dan tanggungjawab untuk melakukan pengabdian kepada masyarakat. Sebagai khalifatullah, manusia termasuk para santri di dalamnya mempunyai dua tugas utama. Pertama, ibadatullah, yaitu beribadah dalam arti luas termasuk ibadah yang bermanfaat untuk orang lain. Ibadah yang bernuansa sosial ini di kalangan ahli fiqih disebut ibadah muta'addiyah yang pahalanya lebih utama. Tugas santri yang kedua, ungkap Kyai Nasruddin adalah "maratu al ardhi" yang meliputi membangun, mengelola dan memelihara bumi sebagai upaya untuk menunjang kelancaran tugas ibadah. Tugas kedua ini telah diisyaratkan oleh Allah melalui QS. Hud : 61 yang artinya :

"Allah adalah yang telah menciptakan kalian dari bumi dan menuntut kalian berdua untuk memakmurkan di bumi, maka mohonlah ampun kepada-Nya dan bertaubatlah kepada-Nya".

Kegiatan pengajian Pesantren Ilmu Giri mengusung konsep pelestarian lingkungan dan pengembangan berbagai budaya dan tradisi masyarakat dengan konsep taman pembelajaran bagi semua warga masyarakat, dari usia dini hingga usia lanjut. Diantara kekhasan pesantren ini yang tidak dipunyai oleh institusi pesantren pada umumnya adalah untuk memberbadayakan dan mencetak generasi religius, para santri dibimbing dengan memanfaatkan kekayaan alam sekitar dengan menonjolkan kearifan lokal.

Materi yang diajarkan ustad kepada para santri di Pesantren Ilmu Giri adalah tiap 10 anak santri diberi tugas mengumpulkan daun sebanyak-banyaknya untuk diketahui manfaatnya, hasilnya mereka ternyata mengerti dan tahu manfaatnya. Bahkan, kelompok satu berhasil mengumpulkan 30 helai daun yang berbeda, tahu nama daunnya serta mengerti manfaatnya. Seperti penuturan Ustad Mujiono, pengajar TPA Pesantren Ilmu Giri dalam suatu FGD berikut ini:

"Inti pengajaran santri adalah menanamkan pengetahuan dan kearifan dalam hidup mereka, selain mempelajari al-Quran. Materi pengajaran berbasis alam sekitar pesantren, khususnya alam hutan dan budaya tradisi. Santri kita ajak mengenal pohon, kayu, batu, satwa/binatang untuk digali asal muasalnya dan manfaatnya. Targetnya setelah mereka keluar dari pesantren, maka akan muncul pemuda-pemuda yang paham agama, tetapi juga perduli pada lingkungan alam dan budaya tradisi."

Terdapat empat hal yang melatarbelakangi Pesantren Ilmu Giri berhasil dalam kegiatan menumbuhkan kesadaran lingkungan, yaitu : a. Modal sosial dan modal spiritual. Modal sosial dalam konteks riset ini adalah bagian-bagian dari organisasi sosial seperti kepercayaan, norma dan jaringan yang dapat meningkatkan efisiensi masyarakat dengan memfasilitasi tindakantindakan yang terkoordinasi. Termasuk jejaring dari pertalian warga masyarakat dan norma-norma sosial. Modal sosial yang dibangun di Pesantren Ilmu Giri, diukur dengan tingkat kepercayaan di masyarakat, saling merasakan, empati, serta komitmen terhadap kesehatan masyarakat. Ini dibentuk oleh kecerdasan emosional (EQ), berfungsi menjawab pertanyaan-pertanyaan yang menyangkut perasaan, seperti, "apa yang saya rasakan".

b. Modal spiritual juga melampaui modal sosial, yaitu kekayaan material dan keuntungan sosial yang didapat suatu masyarakat dengan mengandalkan sikap saling percaya (trust). Modal spiritual-di dalamnya termasuk modal moral-dibentuk oleh kecerdasan spiritual (SQ), dibangun dengan mengeksplorasi secara spiritual pertanyaanpertanyaan seperti "untuk apa saya ada, apa tujuan hidup saya, apa yang sebenarnya ingin saya capai". Modal spiritual yang dimiliki oleh pengasuh Pesantren Ilmu Giri diperoleh dari perjalanan hidup panjang yang selama ini dijalani dan dimaknai sebagai sebuah hal positif, didukung pemahaman keagamaan (kitab-kitab rujukan) yang diperoleh. Modal spiritual didukung oleh kemampuan pemahaman terhadap al-Qur'an dan kitab-kitab rujukan diantaranya surah Ali Imran:104, Surah Al-Ara'af : 179, Surah AtTakattsur : 1-8, Kitab Al-Hikam karangan Syekh Ibnu Athaillah as-Sakandari, Kitab Ihya Ulumuddin karangan Imam Al-Ghazali, dan Tafsir At Thabari karangan Ibnu Jarir Ath Thabari.

c. Ketokohan, strategi kepemimpinan dan jaringan pengasuh pesantren. Pesantren Ilmu Giri dikenal khalayak karena jejaring yang dimiliki oleh pengasuh pesantren dengan secara aktif mengkampanyekan pelestarian lingkungan melalui nilai-nilai spiritual agama, yang diwujudkan dalam bentuk-bentuk ritual keagamaan, disamping aktivitas-aktivitas lain baik di bidang pendidikan, ekonomi, sosial maupun budaya. Kekuatan networking yang dimiliki oleh pengasuh pesantren mampu mendatangkan banyak bantuan baik dari berbagai kalangan. Ketokohan, strategi kepemimpinan dan networking tadi didukung oleh dua modal utama, yaitu modal spiritual dan modal kepekaan terhadap fenomena kemanusian (kebodohan, kemiskinan, ketertinggalan), 
kerusakan lingkungan, sosial dan budaya. Sebagai gambaran Gambar 3 berikut ini menggambarkan pemangku kepentingan yang berperan dalam pengembangan Pesantren Ilmu Giri.

d. Dukungan dan pelibatan warga masyarakat sebagai subjek pemberdayaan pesantren. Dukungan warga masyarakat dalam konteks yang luas, meliputi warga Nogosari, jamaah mujahadah, santri dan tentunya pengasuh pesantren/ustad lainnya.

e. Dukungan Pemberitaan Media Massa (Pers). Ustad Nasruddin Anshoriy Ch berhasil memanfaatkan media, khususnya surat kabar untuk memberitakan perkembangan Pesantren Ilmu Giri. Telah banyak ekspose media lokal dan nasional terkait dengan aktivitas Pesantren Ilmu Giri dan pengasuhnya, mayoritas berita mengangkat aktivitas pesantren, termasuk pengelolaan lingkungan dan pemberdayaan masyarakat.

\section{KESIMPULAN}

Beberapa kesimpulan dapat dirumuskan sebagai berikut :

1. Bentuk pengelolaan lingkungan yang dikembangkan oleh Pesantren Ilmu Giri hasil kemitraan dengan masyarakat mencakup empat hal, yaitu:

a. Penghijauan melalui hutan santri dengan konsep eco-religi sebagai identitas baru petani Desa Selopamioro hasil kemitraan pesantren dan masyarakat. Sejak dicetuskannya pada tahun 2005, hutan santri Ilmu Giri sampai saat ini telah mencapai luas 55 hektar dengan 126 anggota/petani.

b. Pesantren Ilmu Giri menggali, mengangkat dan melestarikan budaya tradisi lokal. Pesantren mengembangkan event-event budaya dan tradisi Jawa, pengembangan potensi seni musik religi tradisonal, seperti group shalawatan, jathilan, wayang wong, gejok lesung, teater rakyat, musik hadrah, group dangdut tradisional dan lain sebagainya yang secara rutin ditampilkan disela acara mujahadah, hari besar Islam dan peringatan hari bumi/lingkungan hidup.

c. Pesantren Ilmu Giri berhasil mengangkat ekonomi masyarakat melalui lahirnya Lembaga Keuangan Mikro (LKM). Lahirnya LKM BMT Talang Emas atas inisiatif Pesantren Ilmu Giri bermitra dengan masyarakat Nogosari.

d. Pesantren Ilmu Giri mengkampayekan makanan ekologis dan menolak penggunaan pupuk kimia dan pestisida. Pesantren Ilmu Giri dengan konsep pemberdayaan masyarakat lokal yang digagasnya mengkampanyekan makanan organik yang halal tanpa pemanis, pengawet dan pewarna, yang kesemuannya bisa ditemukan sekitar pesantren, seperti ubi, singkong, jagung, pisang, kelapa serta aneka buah yang sengaja ditanam warga.

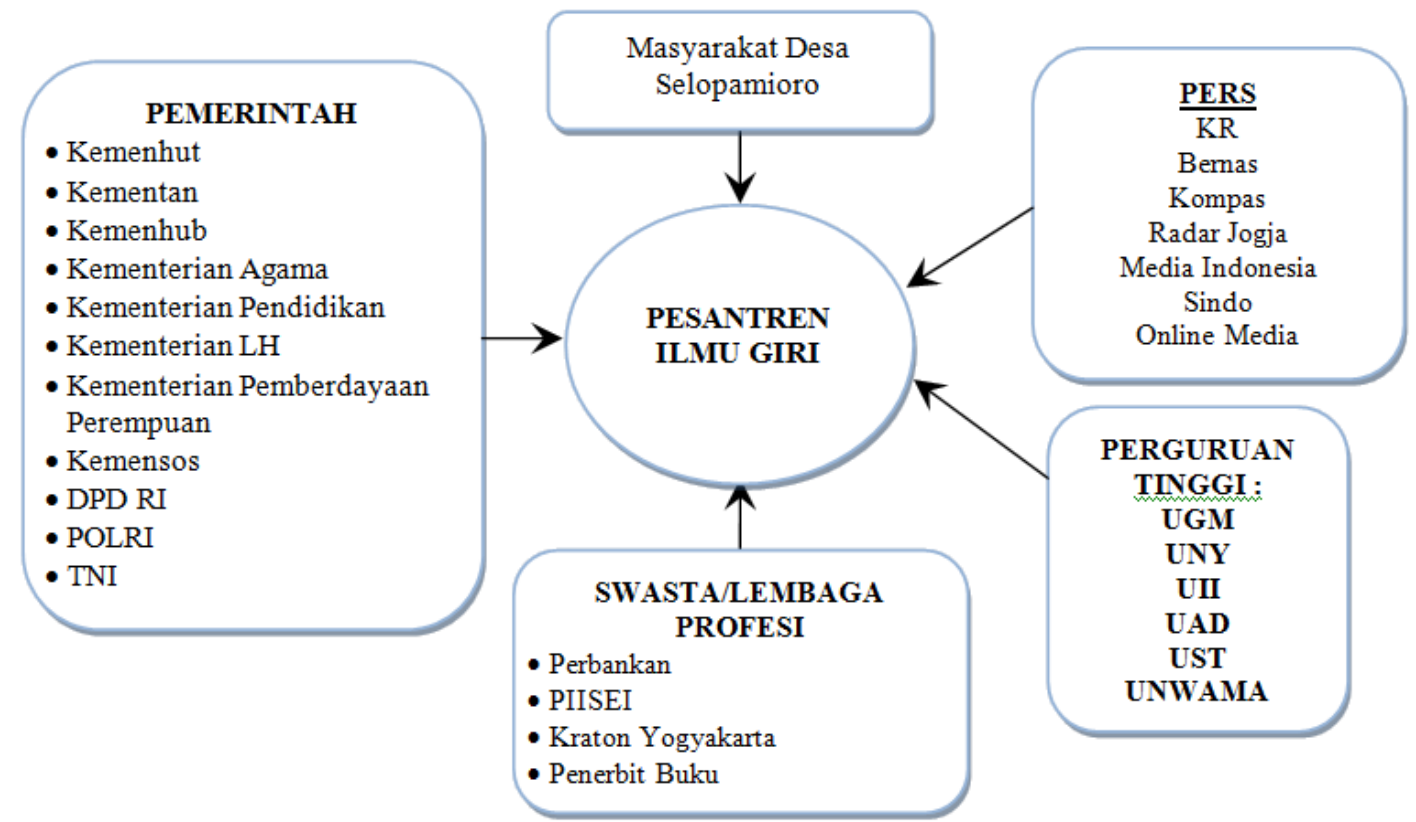

Gambar 3. Stakeholders yang Berperan di Pesantren Ilmu Giri 
2. Pesantren Ilmu Giri tidak menggunakan kurikulum sebagaimana lazimnya pada pesantren-pesantren modern yang memiliki santri dan pondok. Pesantren Ilmu Giri hanya memiliki jamaah binaan warga yang bergabung dalam sebuah komunitas yang disebut jamaah mujahadah serta santri Taman Pendidikan Al-Qur'an (TPA). Jamaah mujahadah dan santri TPA inilah yang menjadi sasaran dakwah pengasuh pesantren. Inti pengajaran bagi jamaah dan santri adalah menanamkan pengetahuan dan kearifan dalam hidup mereka, selain mempelajari al-Quran. Subjek pengajaran berbasis alam sekitar pesantren, khususnya terkait dengan etika lingkungan dan pemberdayaan masyarakat. Targetnya setelah mereka keluar dari pesantren, maka akan lahir pemuda-pemudi yang paham agama, dan perduli pada lingkungan alam dan budaya tradisi.

3. Empat hal yang melatarbelakangi Pesantren Ilmu Giri berhasil dalam kegiatan menumbuhkan kesadaran lingkungan, yaitu : pertama modal sosial dan modal spiritual pengasuh pesantren; kedua ketokohan dan strategi kepemimpinan pengasuh pesantren; ketiga dukungan warga sekitar pesantren, dan keempat dukungan pemberitaan media massa (pers) terkait dengan kegiatan pesantren. Selain keberhasilan, juga ditemukan beberapa kendala/kelemahan dalam pengelolaan lingkungan berbasis pesantren di Pesantren Ilmu Giri, yaitu (a) pendidikan masyarakat rendah sehingga sulit dalam menerima kampanye pelestarian lingkungan; (b) merubah pola pikir masyarakat terhadap lingkungan; (c) tingkat ekonomi masyarakat yang rendah; (d) ketersedian air bersih yang terbatas; (e) domisili pengasuh jauh dari pesantren; (f) konflik pengasuh pesantren dan masyarakat lokal.

\section{DAFTAR PUSTAKA}

Anonim. (2009). Undang-Undang Nomor 32 Tahun 2009 tentang Perlindungan dan Pengelolaan Lingkungan Hidup. Kementerian Lingkungan Hidup. Jakarta

(1999). Undang-Undang Nomor 41 Tahun 1999 tentang Kehutanan. Kementerian Kehutanan. Jakarta

A'dam, Syahrul. (2007). Konsep dan Teknik Penyusunan Materi Dakwah Konservasi Alam dan Lingkungan.

Anshoriy dan Sudarsono. (2008). Kearifan Lingkungan dalam Perspektif Budaya Jawa. Yayasan Obor Indonesia.
Ali Yafie et all. 1997. Islam dan Lingkungan Hidup. Jakarta. Yayasan Swarna Bhumi.

Baiquni dan Susilawardani. (2002). Pembangunan yang tidak Berkelanjutan; Refleksi Pembangunan Indonesia. Yogyakarta. Transmedia Global Wacana.

Gardner. (2002). Invoking the Spirit Religion and Spirituality in the Quest for a Sustainable World. USA. Worldwatch Institute.

Hardjasoemantri, K. (2005). Hukum Tata Lingkungan. Edisi Kedelapan. Yogyakarta. Gadjah Mada Press.

Hasbullah. (1999). Sejarah Pendidikan Islam di Indonesia : Lintasan Sejarah Pertumbuhan dan Perkembangan. Jakarta .PT Raja Grafindo Persada.

Ka'ban, M.S. (2007). Pengelolaan Lingkungan Hidup dalam Perspektif Islam. Jurnal Millah. VI(2).

Madjid, Nurcholish. (1997). Bilik-Bilik Pesantren. Jakarta. Paramadina.

Mangunjaya, dkk. (2007). Menanam Sebelum Kiamat; Islam, Ekologi dan Gerakan Lingkungan Hidup. Penerbit : Yayasan Obor Indonesia

Mahfuzd, Sahal. (2004). Wajah Baru Fiqih Pesantren. Jakarta. Citra Pustaka.

Tucker, Mary Evelyn dan John, A. Grim. (2003). Agama, Filsafat dan Lingkungan, terj. Hardono Hadi. Yogyakarta. Kanisius.

Qodar. (2014). Manajemen Kepemimpinan Lingkungan, Kajian Eko-Sufisme Pesantren. Yogyakarta. Ilmu Giri.

Salim, E. (2006). Pengelolaan Lingkungan dalam Pembangunan. Disampaikan sebagai bahan kuliah Pasca Sarjana (S3). Bogor. Program Studi PSL IPB.

Setiawan, dkk. (2000). Pengelolaan Sumberdaya dan Lingkungan. Edisi Kedua. Yogyakarta. Gadjah Mada University Press.

(2007). Prinsip-Prinsip dan Kebijakan Pengelolaan Lingkungan Hidup di Indonesia. Paper Matakuliah Manajemen Lingkungan S2 Ilmu Lingkungan UGM. Tidak dipublikasikan . (2007). Review Persoalan Lingkungan. Paper Matakuliah Manajemen Lingkungan S2 Ilmu Lingkungan UGM. Tidak dipublikasikan

Sutikno. (1982). Peranan Geomorfologi dalam AspekAspek Keteknikan. Makalah Seminar Geografi II dengan tema Peranan Geografi dalam Pembangunan Nasional. Yogyakarta. IGEGAMA.

Suwito, N.S. (2011). Eko-Sufisme, Konsep, Strategi, dan Dampak. Seri Disertasi. Purwokerto. STAIN Press. 